\title{
Evaluation of Pollution Due to Gold Mining at Ity-Floleu Area in Sub-Prefecture of Zouan-Hounien, Western Côte d'Ivoire
}

\author{
Gbamélé Kouassi Serge ${ }^{\text {1* }}$, Konan Kouakou Séraphin'1, Kouassi Kouakou Lazare², \\ Brou Loukou Alexis ${ }^{2}$, Konan Koffi Félix ${ }^{3}$, Bini Kouamé Dongui ${ }^{4}$ \\ ${ }^{1}$ Laboratory of Geosciences and Environment, University Jean Lorougnon Guede, Daloa, Côte d'Ivoire \\ ${ }^{2}$ Departement of Geology, University Jean Lorougnon Guede, Daloa, Côte d'Ivoire \\ ${ }^{3}$ Laboratory of Ecology, Biodiversity and Evolution, University Jean Lorougnon Guede, Daloa, Côte d'Ivoire \\ ${ }^{4}$ Laboratory of Environment Chemistry and Materials, University Jean Lorougnon Guede, Daloa, Côte d'Ivoire \\ Email: *sergegbamele@gmail.com, konandks@yahoo.fr
}

How to cite this paper: Serge, G. K., Séraphin, K. K., Lazare, K. K., Alexis, B. L., Félix, K. K., \& Dongui, B. K. (2019). Evaluation of Pollution Due to Gold Mining at Ity-Floleu Area in Sub-Prefecture of ZouanHounien, Western Côte d'Ivoire. Journal of Geoscience and Environment Protection, 7, 20-41.

https://doi.org/10.4236/gep.2019.712002

Received: November 4, 2019

Accepted: December 13, 2019

Published: December 16, 2019

Copyright $\odot 2019$ by author(s) and Scientific Research Publishing Inc. This work is licensed under the Creative Commons Attribution International License (CC BY 4.0).

http://creativecommons.org/licenses/by/4.0/

\begin{abstract}
This study aims to evaluate the mineral pollution of a gold mining environment in the sub-Prefecture of Zouan-Hounien (Côte d'Ivoire). Samples were taken from surface water and flesh and skin samples of the Cavally River fish species over a period of two successive years. Concentrations in major elements, trace elements $\left(\mathrm{As}, \mathrm{Cd}, \mathrm{Cr}, \mathrm{Cu}, \mathrm{Hg}, \mathrm{Ni}, \mathrm{Pb}\right.$ and $\mathrm{Zn}$ ), nutrients $\left(\mathrm{NO}_{3}^{-}\right.$, $\mathrm{NO}_{2}^{-}, \mathrm{NH}_{4}^{+}, \mathrm{PO}_{4}^{-}, \mathrm{SO}_{4}^{2-}$ ) and physico-chemical parameters in situ were measured. The results obtained show that the surface waters have very low $\mathrm{pH}$ with an average of 5.70. For nutrient salts, the deterioration of water quality in the study area is mainly related to alterations by nitrates, phosphates and sulphates. The concentrations of $\mathrm{Fe}, \mathrm{Cu}, \mathrm{Hg}$ and $\mathrm{Pb}$ are above the existing standards (international, $\mathrm{FAO} / \mathrm{WHO}$ ) for the majority of the stations, thus causing the deterioration of the surface water quality. Therefore, their use for agricultural irrigation could have negative impact on the health of the population and on biodiversity. Regarding the bioindicating species, the results obtained after analysis of samples showed that the fish (carp and machoiron) have $\mathrm{Fe}, \mathrm{Cu}, \mathrm{Hg}$ and $\mathrm{Pb}$ concentrations higher than the existing standards (international, $\mathrm{FAO} / \mathrm{WHO}$ ) exposing consumers to high health risks. This study showed good correlation between the high values of surface water turbidity and the proximity of gold washing sites. The use of the principal component analysis (PCA) of the physicochemical dataset revealed comparable behaviors for certain minerals within the groups ( $\mathrm{Fe}, \mathrm{K}, \mathrm{Mg}, \mathrm{Mn}$ and $\mathrm{Na}$ ) and (As, $\mathrm{Cd}, \mathrm{Cu}, \mathrm{Ni}, \mathrm{Pb}, \mathrm{Zn}$ and $\mathrm{Ca}$ ) in water. The Ascending Hierarchical Classification (AHC) analysis has defined three different classes of surface water in
\end{abstract}


the study area. The presence of mineral trace elements in these receiving environments is of natural origin but would be strongly accentuated by human activities.

\section{Keywords}

Cavally River, Fish, Gold Mining, Major Elements, Nutritious Salts, Surface Water, Trace Elements

\section{Introduction}

The Côte d'Ivoire economy was essentially based on agriculture since its independence in 1960. Mining activities did not play a major role in the economy. However, the significant mining discoveries of the last thirty (30) years have led the Ivorian Government to put a particular emphasis on the development policy of the mining sector in order to revitalize it (Atsé, 2007). Mining development is valued by some as a positive factor in terms of socio-economic benefits. However, it is incriminated by others for its negative environmental impacts (Ripley et al., 1996; Aubertin et al., 2002; Brigde, 2004) especially in remote areas of urban, underdeveloped areas where indigenous communities live which part of the traditional way of life depends on the ecological integrity of the territory (Scott, 2002). By its harmful effects, it can cause critical situations (loss of all aquatic life, mineral intoxication of the population) or even dangerous sometimes affecting the ecological balance of these ecosystems (Makhoukh et al., 2011, Pétré, 2008). Contamination of aquatic ecosystems by minerals can be confirmed in water, sediment and organisms (Forstner \& Wittman, 1983). Numerous studies have shown the potential action of fish consumption in the prevention of cardiovascular disease and coronary disease (Daviglus et al., 1997, Kris-Etherton, 2002), stroke (He et al., 2004), some cancers (Hirose et al., 2003, Hughes et al., 2003), depression (Astorg et al., 2008, Timonen et al., 2004), and some neurodegenerative diseases (Huang et al. 2005, Morris et al., 2003). Successive human mercury, cadmium and lead poisoning incidents, highlighted in industrialized countries, have placed the subject of environmental pollution as one of the major challenges of our time. The industrial and technological revolution of the 19th century was accompanied by a significant increase of discharges into the environment by humans of these natural substances or syntheses that have direct or indirect effects on human and environmental health. The environmental impacts related to extractive activities in Côte d'Ivoire are progressing in a worrying way. This results in environmental degradation, the most visible of which are: deforestation, loss of biodiversity, pollution and also health consequences at community and household levels. Also, the toxicity of an ore does not depend only on its concentration but also on its speciation (Mounia, 2013). Indeed, the total content of an element gives only an overall indication of the degree of pollution, but does not allow knowledge of the risk of toxicity associated with the 
element (Sirven, 2006). Speciation determines its fate and transfer in the environment, as well as its bioavailability and toxicity in the environment (Weber, 2006). In Côte d'Ivoire, mineral contamination of ecosystems has attracted the attention of many researchers (Coulibaly et al., 2009, Touré et al., 2010, Keumean et al., 2013). Mineral pollution is a topical issue of concern to the scientific community, which is interested in the quality of life, that is to say the preservation of the environment, which is undermined by human activities and natural disasters. This concern affects the sub-prefecture of Zouan-Hounien, where a significant mining activity has been conducted since 1990. This mining activity is concretized by several artisanal gold mining sites scattered in the sub-Prefecture of Zouan-Hounien and a gold mine-Ity mine fifteen (15) kilometers from the city. Minerals from gold mining operations can be found in rivers and thus in the food chain via the ingestion of these waters or living organisms (fish, crustaceans, etc.) or agricultural products and represent a danger for the human health (Burnol et al., 2004; Pétré, 2008). The objective of this work is to assess the pollution and to determine the impacts generated by the activities on water quality in the mining environment of Zouan-Hounien (Côte d'Ivoire). To achieve goal, analyzes were carried out on surface waters, flesh and skin of fish species of the Cavally River over a period of two successive years.

\section{Material and Method}

\subsection{Study Area}

Ity is a village located $15 \mathrm{~km}$ southeast of Zouan-Hounien (Côte d'Ivoire), its administrative center. The Ity area is moderately rugged with altitudes ranging from $255 \mathrm{~m}$ along the Cavally River to $450 \mathrm{~m}$. The region belongs to a vast forest area that covers both Côte d'Ivoire and Liberia (Ettien, 2010). Located in western Côte d'Ivoire, the Cavally watershed is between latitude $6^{\circ} 47^{\prime}$ and $6^{\circ} 52^{\prime}$ north, and between longitude $8^{\circ} 5^{\prime}$ and $8^{\circ} 6^{\prime}$ west. This catchment area covers an area of $3647.53 \mathrm{~km}^{2}$ with the Floleu hydrometric station as an outlet (Figure 1). With a length of $700 \mathrm{~km}$, the Cavally River is shared by three countries: Côte d'Ivoire, Guinea and Liberia. The Cavally has many meanders and the stream bed is disturbed by gold panning activities (Naho, 1988). Crops grown are mainly coffee, cocoa, palm oil, cassava, rice and banana.

The graph below (Figure 2) showing the annual rainfall amounts indicates that there is alternation of two rainy seasons: long dry season from November to February, short rainy season from March to July, short and dry season from July to end of August, heavy rainy season from September to November. The driest month is January. The greatest amount of precipitation occurs in September. The average annual rainfall is $1866 \mathrm{~mm}$ and the annual average temperature in Zouan-Hounien is $25.6^{\circ} \mathrm{C}$. The study of the variations of the rainfall and the hygrometric degree shows that the rainy regime evolves in the direction of a decrease of the annual precipitations and an aggravation of the dry season. This gradual desiccation is due to the deforestation of the most populated areas, the 


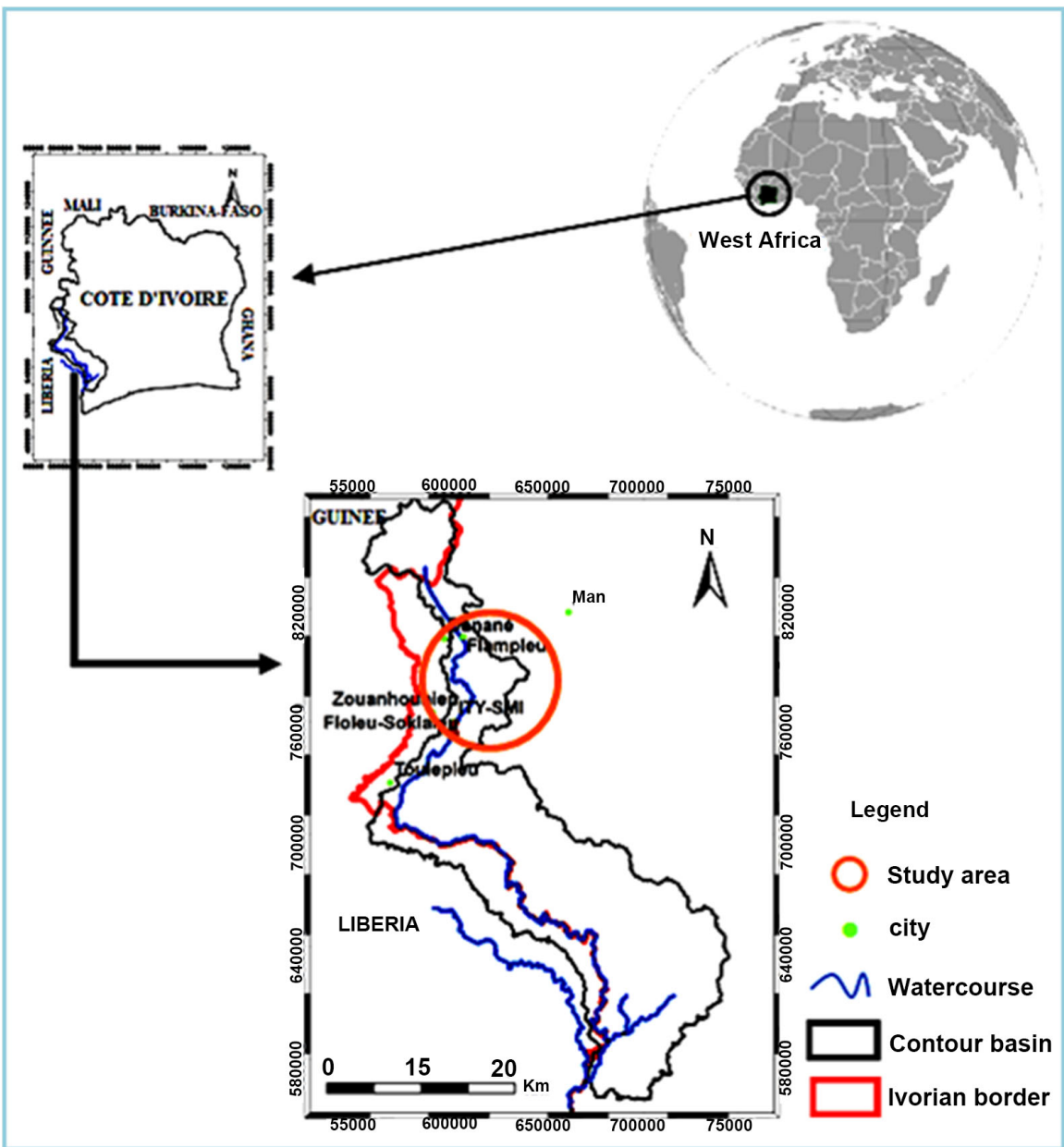

Figure 1. Map of the cavally watershed study area.

population growth leading to the disappearance of primary forest but also secondary forest (Servat et al., 1998; Ouedraogo, 2001). The Cavally River and its tributary Nuon water cover the entire mountain region. However, several villages face severe water shortages during the long and dry season (Ettien, 2005).

Local geology is difficult to define because there is no outcrop in the area. To this difficulty, is added the presence of a dense vegetation cover. The Ity gold deposit is located in the Toulépleu-Ity Birimian unit located west of the Sassandra fault in the Kénema-Man area. This ensemble is oriented in a NE-SW direction (Ettien, 2005). Prospecting between 1962 and 1968 of SODEMI revealed a high gold mineralization in the Ity sector where, in the 1940s and 1950s, there was already intense gold mining activity (Papon, 1973). These gold panning activities are greatly increased today. In the north, the basin is dominated by schist, rhyolite, and migmatite, while in the south it is characterized by metamorphic rocks including, gneisses, and mesozonal formations (Ouedraogo et al., 1989). Erosion, is intensive and rejuvenates soils (Vo Quang \& Guyon, 1966).

\subsection{Sample Collection}

Sampling sites were selected for spatial coverage of the largest area possible and 


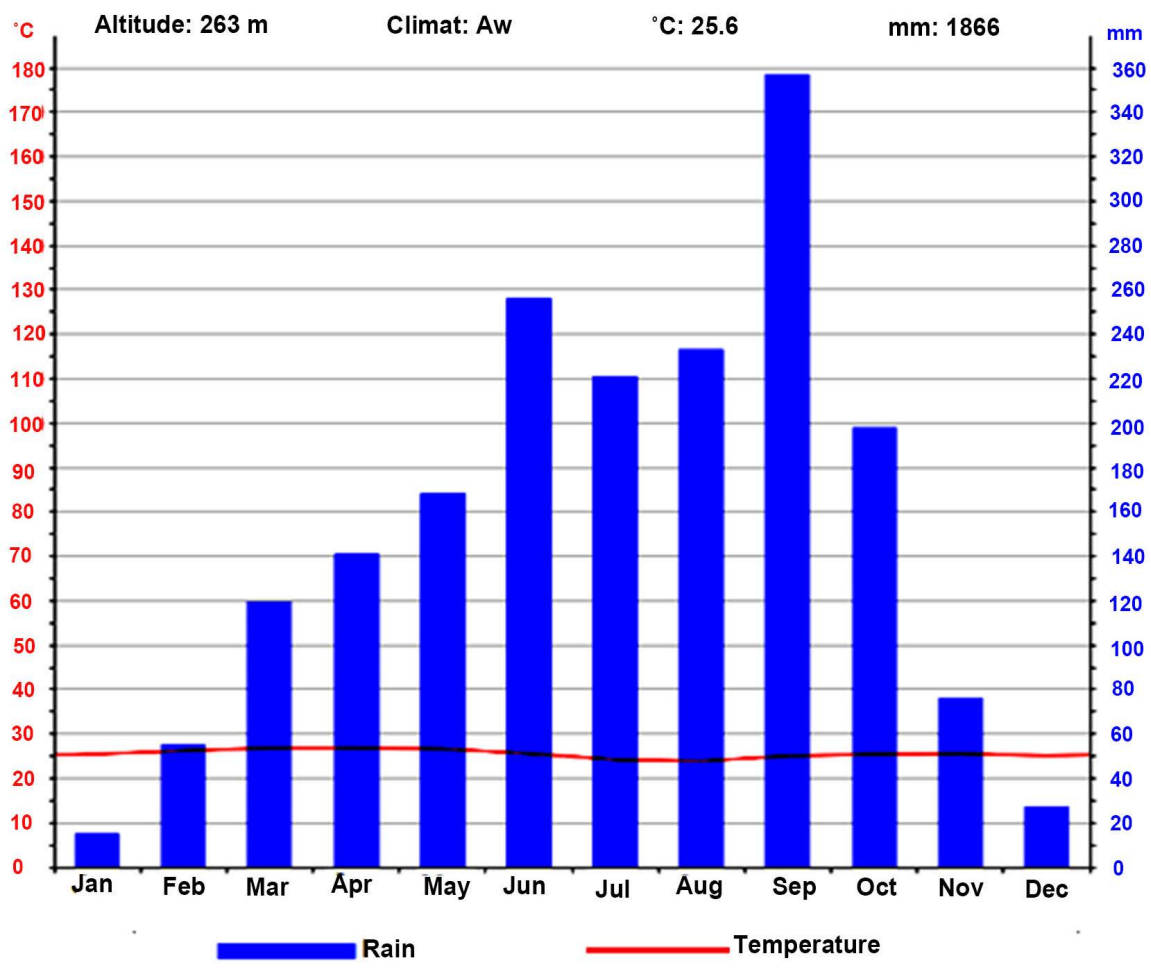

Figure 2. Ombrothermal diagram of the Zouan-Hounien station between 1982 and 2012. (Source:

https://fr.climate-data.org/afrique/cote-d-ivoire/montagnes/zouan-hounien-45180/).

easily accessible by track especially during the rainy season, areas subject to pressure from anthropogenic activities, influence of the course water supplying wells, areas outside the influence of the watercourse. Appropriate measurement campaigns for sampling and analysis are made on surface waters and the flesh of fish species. The measurements were carried out twice during the dry season (low water season) and twice during the rainy season (flood season) over a period of one annual cycle for two consecutive years on the study site. A total of six (6) sampling stations were selected of which twenty four (24) surface water samples and eight (8) samples of two fish species were made at various locations (Figure 3) over the course of four campaigns that began on January 4, 2017 and ended on October 20, 2018. During the study, the samples were taken between 7 am and 4 pm. A Garmin etrex 20 Global Positioning System (GPS) was used for the geographic coordinates of the different sampling stations.

\section{Sampling of surface water}

The water samples were taken using a new $1 \mathrm{~L}$ bottle of polyethylene (PET) plastic, filled to the brim (without leaving any air bubbles) and rinsed with water from the water at the station, acidified in the field with nitric acid $\left(\mathrm{HNO}_{3}\right)$ approximately $1 \mathrm{~N}$ (Rodier, 2009), carefully identified, hermetically closed and stored at $4^{\circ} \mathrm{C}$ in a cooler and then stored in a refrigerator at a temperature below $10^{\circ} \mathrm{C}$ as soon as the field returns to analyze the chemical parameters in the laboratory according to the standards recommended by Afnor (1997) or those approved by Rodier (2009). 


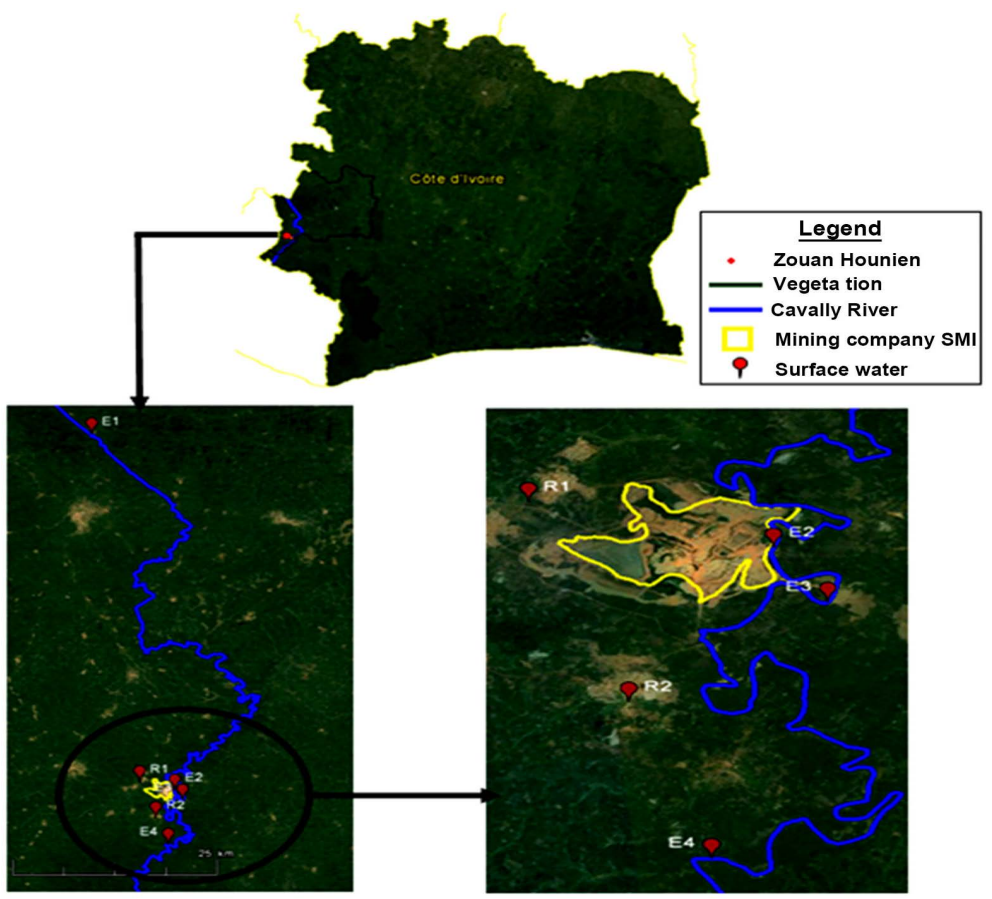

Figure 3. Map of the different sampling stations in the Ity-Floleu study area (Google Earth).

\section{Sampling fish carp and machoirons}

Our study is based on two fish samples: carp (coptodon walteri) and machoiron (chrysichthys teugelsi). This choice is justified by its abundance in our study area and its commercial importance which make it the food of choice for many people. These two species are indicative of pollution and in addition to their socio-economic importance in the catches have different lifestyles and diets. The carp is pelagic and phytoplankton, while the machoiron is benthic and omnivorous (Source: https://animaldiversity.org/) (Figure 4, Figure 5).

The fish were fished in the Cavally River at various points around the SMI-Ity and Floleu-Soklaleu measurement stations in professional fishermen's catches. Two medium samples consisting of two fish of each species were formed before being immediately stored in a cooler below $4^{\circ} \mathrm{C}$ and shipped to the laboratory in accordance with standard quality control procedures. Each campaign, two (02) individuals per species and were collected. A total of sixteen (16) fish were caught for our experiment. For mass and size measurements, we used an OHAUS brand precision scale (model CS 2000-OWO) and an ichthyometer for standard length (Lévêque et al., 1990).

\subsection{Sample Analysis}

Measurements of physico-chemical parameters such as conductivity, temperature, TDS, salinity, $\mathrm{pH}$, redox potential, turbidity are made in situ using a HANNA-brand multiparameter. HI9820, while nitrates $\left(\mathrm{NO}_{3}^{-}\right)$, nitrites $\left(\mathrm{NO}_{2}^{-}\right)$, ammonium ion $\left(\mathrm{NH}_{4}^{+}\right)$, phosphates $\left(\mathrm{PO}_{4}^{-}\right)$and sulphates $\left(\mathrm{SO}_{4}^{2-}\right)$ were analyzed 


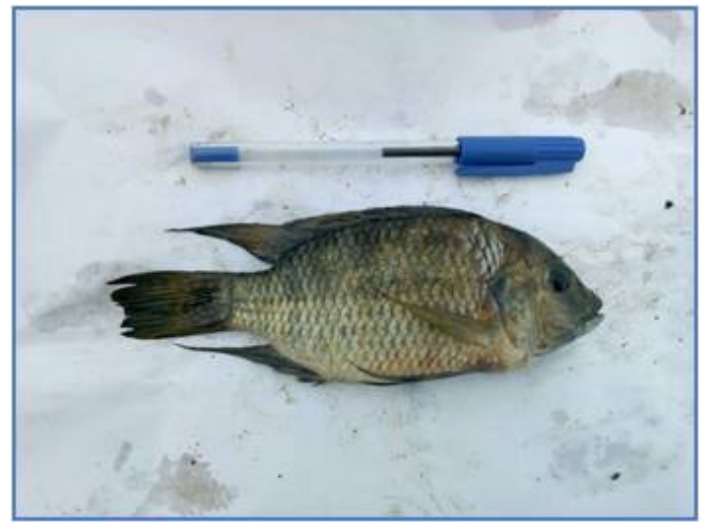

Figure 4. The carp fish.

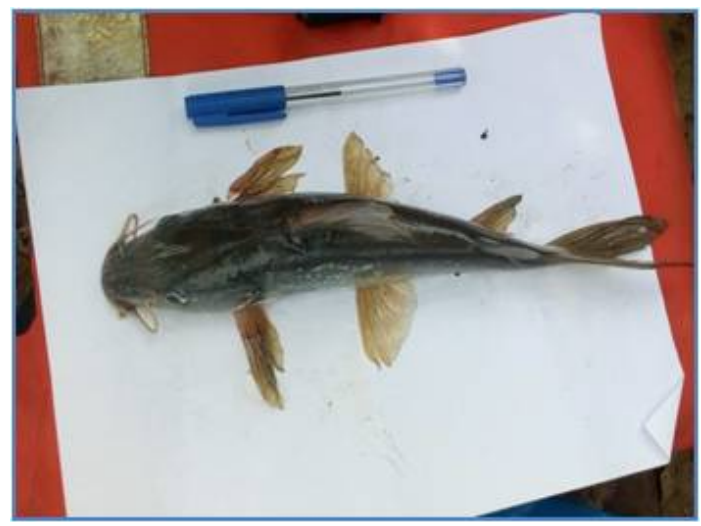

Figure 5. The fish machoiron.

by colorimetric assay using standard methods. As well as the major elements ( $\mathrm{Al}$, $\mathrm{Ca}, \mathrm{Fe}, \mathrm{K}, \mathrm{Mg}, \mathrm{Mn}$ and $\mathrm{Na}$ ) and the mineral trace elements (As, B, Cd, $\mathrm{Cr}, \mathrm{Cu}$, $\mathrm{Hg}, \mathrm{Ni}, \mathrm{Pb}$ and $\mathrm{Zn}$ ) were analyzed by the spectrophotometric method (precision $\pm 1 \mathrm{~nm}$ ) using the Spectra 110 brand ICP-AAS method. The determination of metals in fish flesh and skin is performed by inductively coupled argon plasma optical emission spectroscopy (ICP-OES) type HORIBA JOBIN YVON Ultima 2. This spectrometer operates in simultaneous mode, ie all elements are analyzed at the same time under the same operating conditions. The analyses were conducted at the Ocean Research Center (CRO) in Abidjan (Côte d'Ivoire).

\subsection{Data and Methods}

The results are expressed as means with standard deviations calculated with Excel 2007 software. The comparison of averages, correlations, Principal Component Analyses (PCA) and Ascending Hierarchical Classification (AHC) were done using the XLSTAT statistical software version 2016.02.27444.

\section{Results}

\subsection{Physico-Chemical Parameters of Surface Waters}

The seasonal values of the physico-chemical parameters (temperature, conduc- 
tivity, TDS, salinity, $\mathrm{pH}$, redox potential, turbidity and dissolved oxygen) measured in the surface waters of the Ity mining environment are shown in Table 1.

The surface water temperature is generally low and ranges from $25.38^{\circ} \mathrm{C}$ to $31.10^{\circ} \mathrm{C}$ with an average of $26.82^{\circ} \mathrm{C}$. The conductivity values range from 8.50 to $59.90 \mu \mathrm{S} \cdot \mathrm{cm}^{-1}$ with an average of $22.55 \mu \mathrm{S} \cdot \mathrm{cm}^{-1}$. TDS potential values range from 0 to $17.01 \mathrm{mg} \cdot \mathrm{L}^{-1}$ with an average of $7.07 \mathrm{mg} \cdot \mathrm{L}^{-1}$. Salinity values range from 0 to $45.6 \%$ with an average of $18.29 \%$. The $\mathrm{pH}$ varies from 4.78 to 6.94 and its average is 5.70. The redox potential values are between 13.7 and $49.45 \mathrm{mV}$ and its average is $24.76 \mathrm{mV}$. Turbidity values between 4 and $170 \mathrm{NTU}$ and an average of 49.14 NTU. Dissolved oxygen ranges from 1.77 to $6.92 \mathrm{mg} \cdot \mathrm{L}^{-1}$ with an average of $4.09 \mathrm{mg} \cdot \mathrm{L}^{-1}$.

Table 2 shows that the seasonal mean values per nitrite station range from 0.015 to $0.095 \mathrm{mg} \cdot \mathrm{L}^{-1}$ with an average of $0.038 \mathrm{mg} \cdot \mathrm{L}^{-1}$. The seasonal mean nitrate concentrations per station range from 2.530 to $65.750 \mathrm{mg} \cdot \mathrm{L}^{-1}$ with an average of $14.523 \mathrm{mg} \cdot \mathrm{L}^{-1}$. For ammonium concentrations in surface water, the values per station range from 0.081 to $0.618 \mathrm{mg} \cdot \mathrm{L}^{-1}$ with an average of $0.194 \mathrm{mg} \cdot \mathrm{L}^{-1}$. Mean seasonal phosphate values per station are in the range of 0.160 to $6.825 \mathrm{mg} \cdot \mathrm{L}^{-1}$ with an average of $1962 \mathrm{mg} \cdot \mathrm{L}^{-1}$. Mean sulphate values ranged from 3.460 to $251.165 \mathrm{mg} \cdot \mathrm{L}^{-1}$ with an average of $47.478 \mathrm{mg} \cdot \mathrm{L}^{-1}$.

Table 3 indicates that seasonal mean station concentrations of calcium range from 0.126 to $801 \mathrm{mg} \cdot \mathrm{L}^{-1}$ with an average of $0.900 \mathrm{mg} \cdot \mathrm{L}^{-1}$. The average iron levels per station are between the limit of quantification at $7.183 \mathrm{mg} \cdot \mathrm{L}^{-1}$ with an average of $1.979 \mathrm{mg} \cdot \mathrm{L}^{-1}$. Potassium concentrations range from 0.191 to 12.254 $\mathrm{mg} \cdot \mathrm{L}^{-1}$ with an average of $2.775 \mathrm{mg} \cdot \mathrm{L}^{-1}$. Magnesium levels range from 0.059 to

Table 1. Seasonal variation in physico-chemical parameters of surface water.

\begin{tabular}{|c|c|c|c|c|c|c|c|c|c|}
\hline Stations & Seasons & $\begin{array}{c}\text { Temp } \\
\left({ }^{\circ} \mathrm{C}\right)\end{array}$ & $\begin{array}{c}\text { Cond } \\
\left(\mu \mathrm{S} \cdot \mathrm{cm}^{-1}\right)\end{array}$ & $\begin{array}{c}\text { TDS } \\
\left(\mathrm{mg} \cdot \mathrm{L}^{-1}\right)\end{array}$ & $\begin{array}{l}\text { Sal } \\
(\%)\end{array}$ & $\mathrm{pH}$ & $\begin{array}{c}\text { Potred } \\
(\mathrm{mV})\end{array}$ & $\begin{array}{l}\text { Turb } \\
\text { (NTU) }\end{array}$ & $\begin{array}{l}\text { Oxydis } \\
\left(\mathrm{mg} \cdot \mathrm{L}^{-1}\right)\end{array}$ \\
\hline \multirow{2}{*}{$\mathrm{E}_{1}$} & DS & 25.67 & 25.40 & 6.67 & 45.51 & 6.94 & 22.45 & 4 & 6.23 \\
\hline & RS & 25.94 & 8.50 & 4.00 & 0.00 & 5.89 & 49.45 & 18 & 3.14 \\
\hline \multirow{2}{*}{$\mathrm{E}_{2}$} & DS & 26.47 & 26.05 & 6.61 & 45.55 & 5.75 & 18.25 & 9 & 6.92 \\
\hline & RS & 26.06 & 13.00 & 6.50 & 0.00 & 4.78 & 34.80 & 42 & 3.07 \\
\hline \multirow{2}{*}{$\mathrm{E}_{3}$} & DS & 26.71 & 25.85 & 6.10 & 45.60 & 5.46 & 16.95 & 9 & 6.31 \\
\hline & RS & 26.27 & 9.00 & 4.50 & 0.00 & 5.14 & 24.50 & 31 & 2.54 \\
\hline \multirow{2}{*}{$\mathrm{E}_{4}$} & DS & 26.20 & 22.30 & 5.21 & 45.25 & 5.91 & 13.70 & 107 & 2.24 \\
\hline & RS & 26.11 & 9.00 & 4.00 & 0.00 & 4.94 & 27.75 & 21 & 5.87 \\
\hline \multirow{2}{*}{$\mathrm{R}_{1}$} & DS & 27.08 & 28.80 & 7.35 & 10.85 & 5.31 & 15.25 & 4 & 3.64 \\
\hline & RS & 31.10 & 9.50 & 5.00 & 0.00 & 6.19 & 19.25 & 67 & 1.77 \\
\hline \multirow{2}{*}{$\mathbf{R}_{2}$} & DS & 25.38 & 59.90 & 17.01 & 17.69 & 6.62 & 15.65 & 170 & 2.74 \\
\hline & RS & 26.06 & 10.00 & 5.00 & 0.00 & 5.48 & 25.50 & 32 & 4.58 \\
\hline \multicolumn{2}{|c|}{ WHO standards } & & 1000 & 1000 & & $6.5-8.5$ & & 5 & $4-6^{*}$ \\
\hline
\end{tabular}

DS: Dry season; RS: Rainy season; ${ }^{\star}$ Belgian standard; Temp: temperature, Cond: conductivity, Sal: salinity, Potred: redox potential, Turb: turbidity, Oxydis: dissolved oxygen. 
Table 2. Seasonal variation of nutrient salts (in $\mathrm{mg} \cdot \mathrm{L}^{-1}$ ) of surface waters.

\begin{tabular}{|c|c|c|c|c|c|c|}
\hline Stations & Seasons & $\mathrm{NO}_{2}^{-}$ & $\mathrm{NO}_{3}^{-}$ & $\mathbf{N H}_{4}^{+}$ & $\mathbf{P O}_{4}^{3-}$ & $\mathbf{S O}_{4}^{2-}$ \\
\hline \multirow{2}{*}{$\mathrm{E}_{1}$} & DS & 0.015 & 2.530 & 0.084 & 2.080 & 5.170 \\
\hline & RS & 0.025 & 9.500 & 0.153 & 0.265 & 5.365 \\
\hline \multirow{2}{*}{$\mathrm{E}_{2}$} & DS & 0.042 & 9.340 & 0.168 & 4.370 & 19.740 \\
\hline & RS & 0.029 & 9.900 & 0.092 & 0.295 & 3.460 \\
\hline \multirow[b]{2}{*}{$\mathrm{E}_{3}$} & DS & 0.026 & 9.480 & 0.138 & 1.435 & 7.015 \\
\hline & RS & 0.027 & 10.050 & 0.142 & 0.310 & 7.850 \\
\hline \multirow{2}{*}{$\mathrm{E}_{4}$} & DS & 0.095 & 3.200 & 0.200 & 6.825 & 51.200 \\
\hline & RS & 0.021 & 3.950 & 0.117 & 0.270 & 251.165 \\
\hline \multirow{2}{*}{$\mathrm{R}_{1}$} & DS & 0.025 & 4.495 & 0.081 & 1.895 & 4.910 \\
\hline & RS & 0.053 & 65.750 & 0.618 & 0.285 & 5.150 \\
\hline \multirow{2}{*}{$\mathbf{R}_{2}$} & DS & 0.034 & 2.850 & 0.119 & 2.295 & 41.505 \\
\hline & RS & 0.024 & 4.000 & 0.104 & 0.160 & 7.540 \\
\hline \multicolumn{2}{|c|}{ WHO standards } & 3 & 50 & 1.5 & 0.5 & 250 \\
\hline
\end{tabular}

Table 3. Seasonal variation of major elements (in $\mathrm{mg} \cdot \mathrm{L}^{-1}$ ) of surface waters.

\begin{tabular}{cccccccc}
\hline Stations & Seasons & $\mathrm{Ca}$ & $\mathrm{Fe}$ & $\mathrm{K}$ & $\mathrm{Mg}$ & $\mathrm{Mn}$ & $\mathrm{Na}$ \\
\hline $\mathrm{E}_{1}$ & $\mathrm{DS}$ & 1.662 & 7.183 & 0.676 & 0.364 & 0.091 & 4.900 \\
& $\mathrm{RS}$ & 1.102 & 0.294 & 12.254 & 0.207 & 0.050 & 35.875 \\
$\mathrm{E}_{2}$ & $\mathrm{DS}$ & 0.619 & $<0.05$ & 0.938 & 0.167 & 0.006 & 6.704 \\
& $\mathrm{RS}$ & 1.801 & 0.740 & 2.960 & 0.196 & 0.008 & 3.931 \\
$\mathrm{E}_{3}$ & $\mathrm{DS}$ & 0.586 & 0.335 & 0.457 & 0.134 & 0.001 & 3.747 \\
& $\mathrm{RS}$ & 0.268 & $<0.05$ & 0.191 & 0.061 & $<0.005$ & 1.732 \\
$\mathrm{E}_{4}$ & $\mathrm{DS}$ & 0.988 & 0.580 & 0.571 & 0.225 & 0.004 & 5.781 \\
& $\mathrm{RS}$ & 0.126 & 0.067 & 0.762 & 0.088 & $<0.005$ & 13.946 \\
$\mathbf{R}_{1}$ & $\mathrm{DS}$ & 1.472 & 0.803 & 1.180 & 0.311 & 0.001 & 6.504 \\
& $\mathrm{RS}$ & 0.333 & 0.246 & 0.247 & 0.059 & $<0.005$ & 2.697 \\
$\mathbf{R}_{2}$ & $\mathrm{DS}$ & 1.225 & 0.104 & 0.404 & 0.266 & 0.004 & 4.108 \\
& $\mathrm{RS}$ & 0.490 & 4.233 & 5.769 & 0.097 & $<0.005$ & 17.269 \\
\hline Internatinal standards & & 20 & & & 1.5 & \\
\hline
\end{tabular}

$0.364 \mathrm{mg} \cdot \mathrm{L}^{-1}$ with an average of $0.184 \mathrm{mg} \cdot \mathrm{L}^{-1}$. The manganese concentrations are between the limit of quantification at $0.091 \mathrm{mg} \cdot \mathrm{L}^{-1}$ with an average of 0.028 $\mathrm{mg} \cdot \mathrm{L}^{-1}$. Sodium content values range from 1.732 to $35.875 \mathrm{mg} \cdot \mathrm{L}^{-1}$ with an average of $10.343 \mathrm{mg} \cdot \mathrm{L}^{-1}$ (Table 4).

The seasonal average station-specific levels of arsenic, cadmium, copper, nick$\mathrm{el}$, lead and zinc all vary from the limit of quantification to $32.556 \mathrm{mg} \cdot \mathrm{L}^{-1}, 0.187$ $\mathrm{mg} \cdot \mathrm{L}^{-1}, 2.117 \mathrm{mg} \cdot \mathrm{L}^{-1}, 0.139 \mathrm{mg} \cdot \mathrm{L}^{-1}$, respectively. $4.952 \mathrm{mg} \cdot \mathrm{L}^{-1}$ and $0.309 \mathrm{mg} \cdot \mathrm{L}^{-1}$. 
Table 4. Seasonal variation of mineral trace elements (in $\mathrm{mg} \cdot \mathrm{L}^{-1}$ ) of surface waters.

\begin{tabular}{|c|c|c|c|c|c|c|c|}
\hline Stations & Seasons & As & Cd & $\mathrm{Cu}$ & $\mathrm{Ni}$ & $\mathrm{Pb}$ & $\mathrm{Zn}$ \\
\hline \multirow{2}{*}{$\mathrm{E}_{1}$} & DS & $<0.005$ & 0.187 & 0.022 & 0.117 & 4.952 & 0.059 \\
\hline & RS & $<0.005$ & $<0.0005$ & 0.123 & $<0.005$ & $<0.005$ & $<0.010$ \\
\hline \multirow{2}{*}{$\mathrm{E}_{2}$} & DS & 8.027 & $<0.0005$ & $<0.005$ & 0.116 & $<0.005$ & $<0.010$ \\
\hline & RS & 0.006 & 0.092 & 1.230 & $<0.005$ & $<0.005$ & 0.309 \\
\hline \multirow{2}{*}{$\mathrm{E}_{3}$} & DS & 3.225 & $<0.0005$ & $<0.005$ & $<0.005$ & 2.602 & 0.231 \\
\hline & RS & $<0.005$ & $<0.0005$ & 1.100 & $<0.005$ & $<0.005$ & $<0.010$ \\
\hline \multirow{2}{*}{$\mathrm{E}_{4}$} & DS & 13.933 & $<0.0005$ & $<0.005$ & $<0.005$ & 0.277 & $<0.010$ \\
\hline & RS & $<0.005$ & $<0.0005$ & 1.200 & $<0.005$ & $<0.005$ & $<0.010$ \\
\hline \multirow{2}{*}{$\mathbf{R}_{1}$} & DS & $<0.005$ & 0.137 & $<0.005$ & $<0.005$ & $<0.005$ & $<0.010$ \\
\hline & RS & 5.500 & $<0.0005$ & 1.470 & $<0.005$ & 1.388 & 0.124 \\
\hline \multirow{2}{*}{$\mathbf{R}_{2}$} & DS & $<0.005$ & $<0.0005$ & $<0.005$ & 0.139 & 0.034 & $<0.010$ \\
\hline & RS & 32.556 & $<0.0005$ & 2.117 & $<0.005$ & 0.663 & $<0.010$ \\
\hline \multicolumn{2}{|c|}{ WHO standards } & 0.01 & 0.003 & 2 & 0.07 & 0.01 & 3 \\
\hline
\end{tabular}

The respective average concentrations are $6.843 \mathrm{mg} \cdot \mathrm{L}^{-1} ; 0.043 \mathrm{mg} \cdot \mathrm{L}^{-1} ; 0.670$ $\mathrm{mg} \cdot \mathrm{L}^{-1} ; 0.037 \mathrm{mg} \cdot \mathrm{L}^{-1} ; 1.062 \mathrm{mg} \cdot \mathrm{L}^{-1}$ and $0.074 \mathrm{mg} \cdot \mathrm{L}^{-1}$.

Given the results of the correlation matrix (Pearson) in Table 5, which contains the parameters, several remarks can be made. The temperature is positively correlated with $\mathrm{NO}_{3}^{-}(\mathrm{r}=0.986), \mathrm{NH}_{4}^{+}(\mathrm{r}=0.985)$. Conductivity is very strongly related to TDS $(r=0.994)$ and to a lesser extent with As $(r=0.868)$. The $\mathrm{pH}$ is positively correlated with $\mathrm{Fe}(\mathrm{r}=0.877), \mathrm{K}(\mathrm{r}=0.851), \mathrm{Mg}(\mathrm{r}=0.821)$ and $\mathrm{Na}(\mathrm{r}=0.839)$. The redox potential is positively correlated with $\mathrm{Fe}(\mathrm{r}=0.849), \mathrm{K}$ $(r=0.873)$ and $\mathrm{Mn}(\mathrm{r}=0.8922)$. Cu is respectively negatively correlated with $\mathrm{Mn}$ $(\mathrm{r}=-0.828)$ and $\mathrm{Pb}(\mathrm{r}=-0.813)$. The major elements are well connected with each other except $\mathrm{Ca}$. There is no correlation between $\mathrm{Cu}$ and $\mathrm{Ni}(\mathrm{r}=0)$.

\subsection{Relationship between Physico-Chemical Parameters in Waters}

As part of this study, we performed a Principal Component Analysis (PCA) of all physico-chemical parameters, some of which were selected as passive variables and others active to differentiate groups of elements that exhibit profile of close concentration in surface waters. The inertia of the main axes was expressed as \% cumulative variance. According to these results, three components (F1, F2 and F3) have eigenvalues greater than 1 and accumulate about $83.06 \%$ of the total variance. These three factors make it possible to significantly represent the cloud of points and contain the maximum of information sought (Figure 6).

The results of the PCA in the space of the variables of the factorial plane (F1-F2) make it possible to indicate that this plane expresses $62.80 \%$ of the variance expressed. The factor F1 (40.08\%) is determined by a first grouping of variables which takes into account $\mathrm{pH}$, Potred, Oxydis, $\mathrm{Ca}, \mathrm{Fe}, \mathrm{K}, \mathrm{Mg}, \mathrm{Mn}, \mathrm{Na}, \mathrm{Cd}$ and $\mathrm{Pb}$. The second component (F2) represents $22.72 \%$ of the total variance. It strongly associates Cond, TDS, Turb and Ni to As (2nd grouping) which opposes 


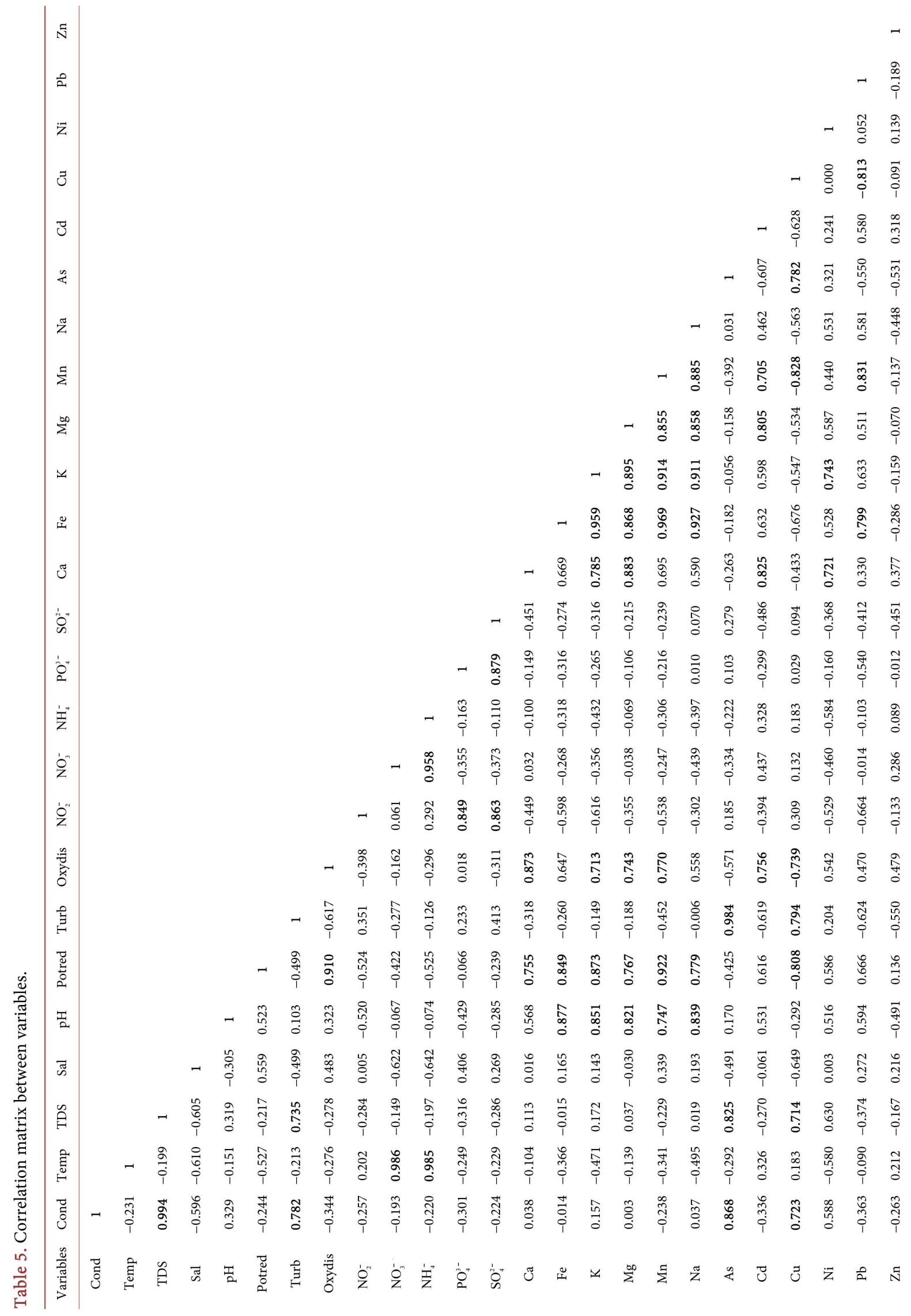




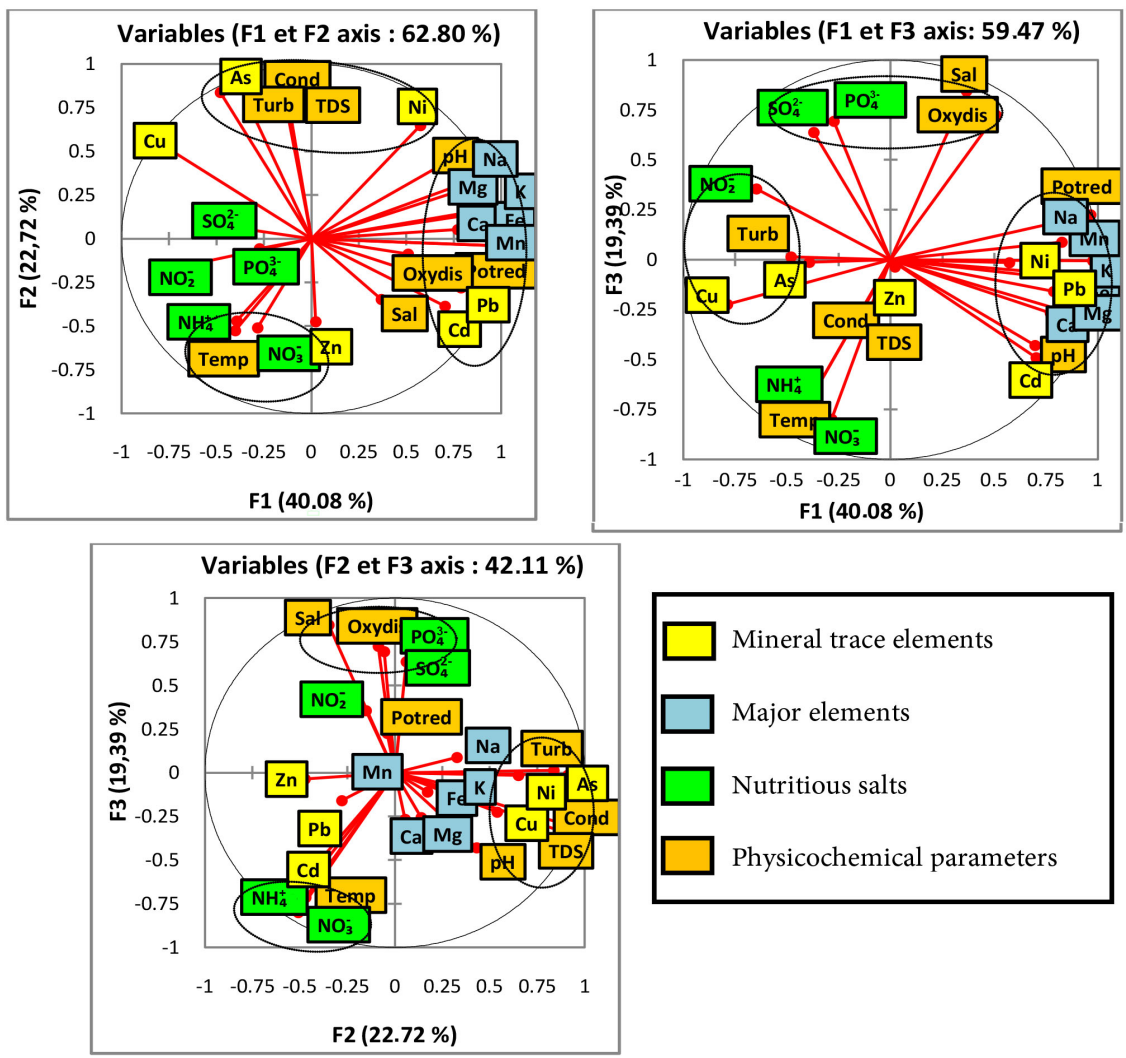

Figure 6. Representation of the concentrations of the physico-chemical parameters in three dimensions according to the factors F1, F2 and F3 in a PCA.

Temp, $\mathrm{NO}_{3}^{-}, \mathrm{NH}_{4}^{+}$, and $\mathrm{Zn}$ (3rd grouping). Finally, the third component (F3) represents about $19.39 \%$ of the total variance. It is associated with Sal, Oxydis, $\mathrm{PO}_{4}^{3-}$, and $\mathrm{SO}_{4}^{2-}$ (4th grouping) which is opposite to Temp, $\mathrm{NO}_{3}^{-}$and $\mathrm{NH}_{4}^{+}$.

Analysis in Ascending Hierarchical Classification (AHC): Figure 7 presents the dendrogram resulting from the classification of surface waters of the region on the basis of all physico-chemical parameters. This dendrogram highlights three groups (high dissimilarity) and subgroups (low dissimilarity). The first group (A) concerns only the river water of the Floleu-Soklaleu $\left(\mathrm{E}_{4}\right)$ station downstream of the study area has the largest pollution of the waters studied. The preponderant phenomenon in the acquisition of pollutants is linked to an intense activity of gold panning and even on the bed of the river. The second group (B) concerns waters with less pollution overall. It takes into account the low-lying water of the village Floleu $\left(\mathrm{R}_{2}\right)$ is influenced by the phenomenon of the pluviolessivage of the soils of mining effluents from gold washing, agricultural and domestic activities. The third grouping (C) consists of intermediate pollution waters. They are: the rice water from the village of Ity $\left(R_{1}\right)$, the river water from the control station taken about $60 \mathrm{~km}$ upstream from the study area $\left(\mathrm{E}_{1}\right)$, the river water located in upstream to the SMI $\left(\mathrm{E}_{2}\right)$ ring road and the river water downstream of the SMI $\left(E_{3}\right)$. Their pollution is influenced by human activities (mining and agriculture). 


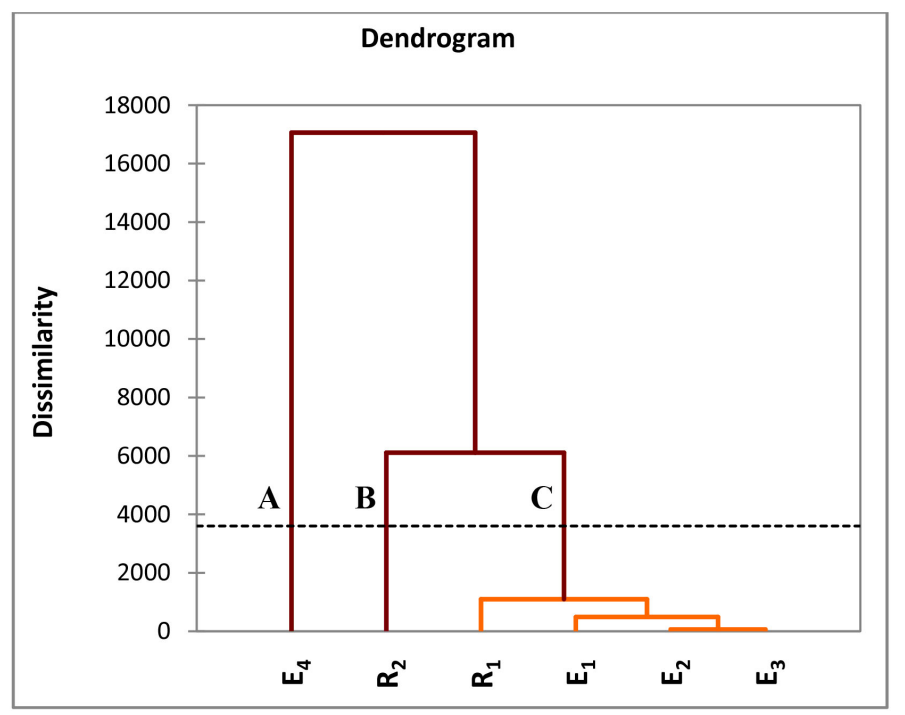

Figure 7. Dendrogram of the surface water classification of the region.

\subsection{Bioaccumulation of Minerals in Fish}

Two species of fish, such as carp (coptodon walteri) and machoiron (chrysichthys teugelsi), fished in the waters of the Cavally River around the SMI-Ity and Floleu-Soklaleu measuring stations were analyzed, including the contents of the minerals studied in the flesh and skin of both species of fish are presented in Table 6.

The iron levels obtained are the most important in carp and machoiron with values between 17.62 and $1137.80 \mathrm{mg} \cdot \mathrm{kg}^{-1}$. The magnesium concentrations detected in machoiron and carp have respective averages of $249.66 \mathrm{mg} \cdot \mathrm{kg}^{-1}$ and $143.06 \mathrm{mg} \cdot \mathrm{kg}^{-1}$. Lead levels in fish samples ranged from 0.41 to $17.80 \mathrm{mg} \cdot \mathrm{kg}^{-1}$ in carp samples and from 0 to $28.90 \mathrm{mg} \cdot \mathrm{kg}^{-1}$ in machoiron samples. The arsenic concentrations in carp ranged from $0.0011 \mathrm{mg} \cdot \mathrm{kg}^{-1}$ to $2.37 \mathrm{mg} \cdot \mathrm{kg}^{-1}$ and in machoiron from 0 to $1.60 \mathrm{mg} \cdot \mathrm{kg}^{-1}$. During both seasons, the iron, arsenic and lead levels found in carp and mace are above $\mathrm{FAO} / \mathrm{WHO}$ or international standards.

The concentrations of cadmium, copper, mercury and nickel in carp fish samples range from 0.01 to $0.66 \mathrm{mg} \cdot \mathrm{kg}^{-1}$, respectively, from 0 to $276.47 \mathrm{mg} \cdot \mathrm{kg}^{-1}$, from 0.0001 to $0.10 \mathrm{mg} \cdot \mathrm{kg}^{-1}$. Carp samples do not show nickel trace. For machoiron, mineral levels in the samples range from 0 to $0.76 \mathrm{mg} \cdot \mathrm{kg}^{-1}$ for cadmium, from 0 to $307.18 \mathrm{mg} \cdot \mathrm{kg}^{-1}$ for copper and from 0.0004 to $0.65 \mathrm{mg} \cdot \mathrm{kg}^{-1}$ for mercury. Nickel was detected during the first dry season with a concentration of $0.01 \mathrm{mg} \cdot \mathrm{kg}^{-1}$. Concentrations of these metals do not meet all FAO/WHO standards in all seasons except for mercury, which is below standard in carp samples.

In our study, the mineral content in the two species of fish presented highlight the phenomenon of bioaccumulation. Iron, arsenic and lead levels do not meet FAO/WHO standards, international and Canadian standards in all seasons, and cadmium, copper, mercury and nickel levels in some seasons.

At the level of the Cavally River around the SMI-Ity and Floleu-Soklaleu measuring stations, a comparison of the heavy metal contents in the flesh and 
Table 6. Concentration of minerals (in $\mathrm{mg} \cdot \mathrm{kg}^{-1}$ ) found in fish carp and machoirons.

\begin{tabular}{cccccccc}
\hline & Fish & \multicolumn{3}{c}{ CARP } & \multicolumn{3}{c}{ CATFISH } \\
\hline Trace elements & WHO standards & Min & Max & Average & Min & Max & Average \\
\hline $\mathrm{Fe}$ & $20^{\mathrm{a}}$ & 17.62 & 1122.66 & 506.81 & 23.35 & 1137.80 & 550.86 \\
$\mathrm{Mg}$ & & 9.49 & 406.99 & 143.06 & 13.77 & 564.35 & 249.66 \\
$\mathrm{As}$ & 0.1 & 0.0011 & 2.37 & 0.88 & $\mathrm{lq}$ & 1.60 & 0.66 \\
$\mathrm{Cd}$ & 0.5 & 0.01 & 0.66 & 0.25 & $\mathrm{lq}$ & 0.76 & 0.39 \\
$\mathrm{Cu}$ & 30 & $\mathrm{lq}$ & 276.47 & 189.84 & $\mathrm{lq}$ & 307.18 & 221.01 \\
$\mathrm{Hg}$ & $0.45^{\mathrm{a}}$ & 0.0001 & 0.10 & 0.04 & 0.0004 & 0.65 & 0.20 \\
$\mathrm{Ni}$ & & $\mathrm{nd}$ & $\mathrm{nd}$ & $\mathrm{nd}$ & $\mathrm{nd}$ & 0.01 & 0.01 \\
$\mathrm{~Pb}$ & 0.5 & 0.41 & 17.80 & 6.06 & 0 & 28.90 & 7.79 \\
\hline
\end{tabular}

ainternational standard, nd: not detected, lq: below the limit of quantification.

skin shows that the fish have higher levels than those of the carp fish except for the arsenic (Figure 8). It is noted that iron concentrations have the highest content in both species followed by copper in carp and magnesium in machoirons.

Regarding the bioindicating species in this region, the results obtained after analysis of our samples showed that fish (carp and machoiron) are contaminated by certain minerals. The concentrations of $\mathrm{Fe}, \mathrm{Cu}, \mathrm{Hg}$ and $\mathrm{Pb}$ are higher than existing standards (international and $\mathrm{FAO} / \mathrm{WHO}$ ). The heavy metals content per fish clearly show that the daily consumption of fish from the Cavally River exposes consumers to high health risks because the levels of these metals are over the above mentioned standards. The risk of accumulation of these metals in the body is real and the harmful effects to be feared.

\section{Discussion}

\subsection{Physico-Chemical Characterization and Water Quality}

The results of in situ surface water analyses show that temperatures reflect those of the ambient atmosphere with values ranging from $21.9^{\circ} \mathrm{C}$ to $35.76^{\circ} \mathrm{C}$ with an average of 26.59. In the sub-Saharan countries of southern Mauritania, Zinsou et al. (2016) find in Benin, relatively high values of $22^{\circ} \mathrm{C}$ to $30.5^{\circ} \mathrm{C}$ with an average of $26^{\circ} \mathrm{C}$, when, in Cameroon, the average surface water temperatures rise to $25^{\circ} \mathrm{C}$ (Aguiza et al, 2014). It is important to note that the water temperature affects the river's aquatic organisms, such as plankton, plants and animals. The fish can be dependent on them for their food or for the production of oxygen by photosynthesis. Admittedly, any abrupt variation of this parameter causes a disturbance in the equilibrium of the aquatic ecosystem (Haddad \& Ghoualem, 2014). These results show that these waters are weakly mineralized, especially during the rainy season (Table 1). The redox potential analyses show that all the waters are in oxidizing conditions except those of the surface waters of the $\mathrm{E}_{1}$ and $\mathrm{R}_{2}$ stations which were under reducing conditions during the first dry season (Table 1). In well-oxygenated water, oxidation conditions dominate. This is 


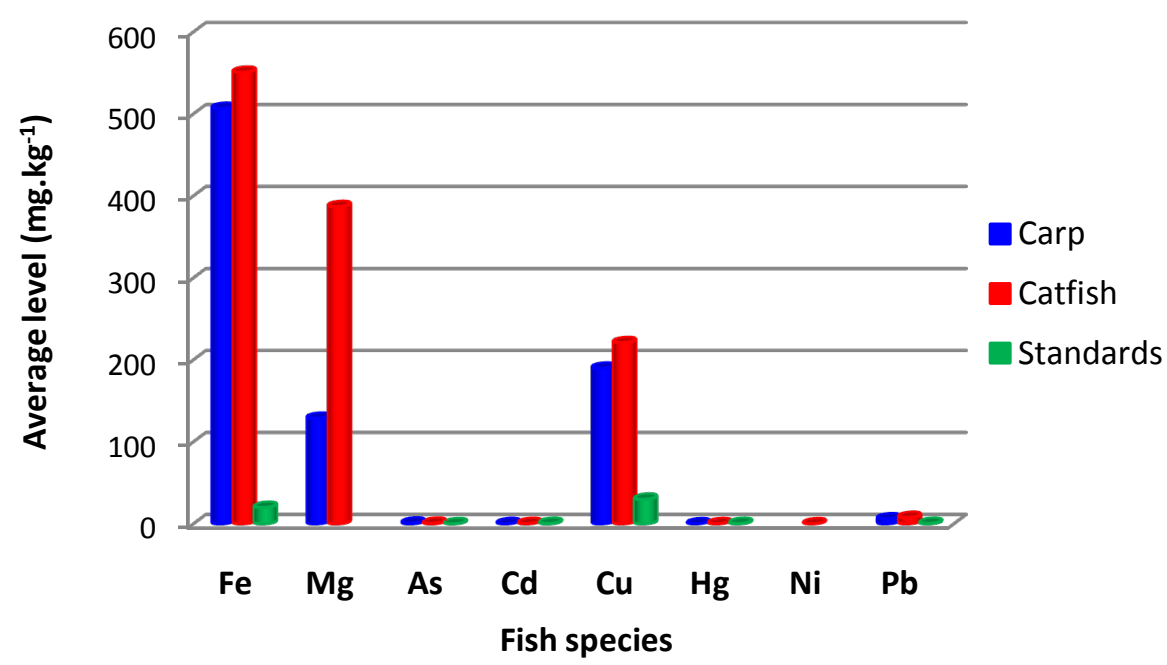

Figure 8. Mean levels of trace mineral elements in the flesh and skin of different fish species.

explained by the fact that the watercourse of this basin is in permanent flow. It has clear waters, with very low or no salinity (except for the first dry season). The analyses show that all the surface water conductivity values of the stations in the study area are below the WHO standard $\left(1000 \mu \mathrm{S} \cdot \mathrm{cm}^{-1}\right)$ during the two successive years. In general, the conductivity of these waters is low compared to those of mineral waters which are between 200 and $1000 \mu \mathrm{S} \cdot \mathrm{cm}^{-1}$ (Hade, 2002). The conductivity of a natural water is between 50 and $1500 \mu \mathrm{S} \cdot \mathrm{cm}^{-1}$ (De Villers et al., 2009). Generalty, the conductivity values are very low. The ionic activity of a solution varies with temperature. The measurement of the electrical conductivity of a solution must therefore always be associated with measurement of temperature. This variation is of the order of $2 \%{ }^{\circ} \mathrm{C}$ (Environment Canada, 1980). Analyses show that all surface waters are acidic with an average of 5.70. The acidity of the surface waters is accentuated during the two years of study during the rainy seasons especially for the river waters of the $\mathrm{F}_{2}$ stations (from 6.34 to 4.53 ) and $\mathrm{F}_{3}$ (from 6.4 to 4.94 ) located respectively upstream and downstream at the river level of the SMI mining company. The lowest $\mathrm{pH}$ occurred at the $\mathrm{E}_{2}$ station. In addition, the acidity of the $\mathrm{E}_{2}$ station (river water) may be due to seepage from the waste rock waste disposal site of the SMI and that of the $\mathrm{F}_{4}$ station where there is intense gold panning activity. In addition, the acidity of the different stations may be due to the redox conditions of the water (Alloway, 1995). Reducing conditions tend to lead to an increase in $\mathrm{pH}$ whereas oxidative conditions decrease it (Alloway, 1995). An additional study is needed to highlight the elements responsible for this acidity. These values, which do not meet the WHO standards $(6.5<\mathrm{pH}<8.5)$, can cause gastric disturbances. In addition, the $\mathrm{pH}$ must be between 6 and 8 to allow aquatic life. The acidity of surface water is consistent with the studies conducted by (Ahoussi et al., 2013) on freshwater in the village of Mangouin-Yrongouin have shown that they are acidic with a $\mathrm{pH}$ that varies between 4.85 and 6.01 . The very high turbidity values at the $\mathrm{E}_{4}$ 
(107 NTU) and $\mathrm{R}_{2}$ (170 NTU) stations during the dry season are due to intense gold panning activity at these sites. Low values of turbidity at several stations during the rainy season could indicate that watercourses are subject to disturbance due to soil leaching for surface water. Turbidity greatly affects the potability of drinking water. Consumers very often have requirements in relation to this parameter.

With regard to nutrients, the degradation of water quality in the study area is mainly related to alterations by nitrates, phosphates, sulphates and to a lesser extent to alteration by organic and oxidizable materials of in terms of ammonium. These elements come mainly from the degradation of the organic matter present in the medium or in the soils leached by the rains (decomposition of the plants and the animals), but also of compounds resulting from the human activity. Indeed, the presence of perennial sources (Cavally River) ensures a continuous renewal of surface water and a dilution of pollutants in the water. In addition, strong flows and assimilation by plants and living organisms such as fish could well explain the absence of high concentrations of nitrogen and phosphorus elements.

Surface waters contain many dissolved elements, the most important among which are sodium $(\mathrm{Na})$, potassium $(\mathrm{K})$, iron $(\mathrm{Fe})$, calcium $(\mathrm{Ca})$. All these surface waters comply with WHO standards for the major elements studied except for iron content. Other elements are only present as traces such as arsenic, lead, copper, zinc, mercury, etc. These results show that the concentrations of As, Cd, $\mathrm{Cu}, \mathrm{Ni}$ and $\mathrm{Pb}$ in surface water are relatively high in the great majority of the studied stations. Apart from $\mathrm{Cr}, \mathrm{Cu}, \mathrm{Hg}$ and $\mathrm{Zn}$, the other metals have levels that far exceed the potency standards set by WHO for the majority of stations, thus causing the deterioration of the quality of these waters. Consequently, their use for agricultural irrigation and the consumption of fish from these surface waters could constitute the risks of bioaccumulation and toxicity and have negative impacts on the health of the population.

\subsection{Origin of Surface Water Pollution from the Ity Mining Environment}

The analysis of the results of the PCA shows a strong association of $\mathrm{Mn}$ and Fe with this F1 component, reflecting their high affinity. In addition, the high levels of these major elements are more or less influenced by the acidic $\mathrm{pH}$ of the medium. The major elements ( $\mathrm{Ca}, \mathrm{Fe}, \mathrm{K}, \mathrm{Mg}, \mathrm{Mn}, \mathrm{Na}$ ) have higher levels in the reference station $\mathrm{F} 1$ than in the surface water stations of the study area and have opposite behaviors to those of $\mathrm{NO}_{2}^{-}, \mathrm{PO}_{4}^{3-}$ and $\mathrm{SO}_{4}^{2-}$ in waters. In a word, the presence of major elements is natural. The origin of the presence of these pollutants is difficult to establish at this stage of the work due to lack of previous data. However, several unknowns such as the anthropogenic influence (due to agricultural or mining activities) of the new entrants and the labile and residual proportions of each element could be at the origin of this pollution. The strong association Cond, TDS, Turb and $\mathrm{Ni}$ with As which opposes the Temp, $\mathrm{NO}_{3}^{-}$, 
$\mathrm{NH}_{4}^{+}$and $\mathrm{Zn}$ being able to have a natural or anthropic origin, this pollution seems to be the reflection of the mixture of anthropic and natural contributions. Nevertheless the association of $\mathrm{Cu}$ with $\mathrm{Ni}$ and $\mathrm{As}$ is influenced by the $\mathrm{pH}$. Indeed, because Ni and As are still linked, it is possible to think that copper has an anthropogenic origin in the studied waters. However, the relationship between $\mathrm{Ni}$ and As in our samples certainly reflects a natural origin. Moreover, the presence of these pollutants suggests that the variables belonging to the same group have comparable behaviors in the waters. The group of $\mathrm{Sal}, \mathrm{PO}_{4}^{3-}$, and $\mathrm{SO}_{4}^{2-}$ which is opposite to Temp, $\mathrm{NO}_{3}^{-}$and $\mathrm{NH}_{4}^{+}$indicating the absence of the ETM could be of natural origin but the presence of $\mathrm{SO}_{4}^{2-}, \mathrm{PO}_{4}^{3-}$ exerts a strong influence on the salinity possibly anthropogenic due to agricultural activities. Therefore, these four groups of variables have incomparable behaviors in the waters. The mineral trace elements come primarily from the erosion of the main rocks of the continental crust. They are naturally present in the environment, but following the leaching of the soils, themselves produced by the alteration of the underlying bedrock. Water plays the role of transport vector, and these elements are found in streams, rivers and rivers in the form dissolved or associated with suspended matter consisting mainly of major elements ( $\mathrm{Ca}, \mathrm{Mg}, \mathrm{Na} . .$.$) .$ From the analysis of the different factorial plans $(\mathrm{F} 1, \mathrm{~F} 2)$ and $(\mathrm{F} 1, \mathrm{~F} 3)$, these groupings show that even if there are different sources of water pollution, some stations have similar sources of pollution. From the analysis in Ascending Hierarchical Classification (AHC), we retain that even if we have different sources of water pollution, some stations have similar sources of pollution.

\subsection{Contamination of Living Organisms}

Two species of fish are thus used as bioindicators of pollution of aquatic environments. It appears that pelagic fish species have less concentrated trace elements than benthopelagic species. This is due to the fact that benthopelagic species are closer to sediments, which are often studied as reservoirs or wells for many chemical pollutants, especially trace elements (Yao et al., 2009; Chouti et al., 2010). Species that are in contact with sediments will be the most contaminated in accordance with their lifestyle. In fact, the benthic species live in a more polluted environment of the aquatic system and feed on benthic organisms. It is shown that chrysichthys teugelsi are omnivorous with dominance of benthic macroinvertebrates (Koné et al., 2007; Diomandé al., 2009). This confirms the results of studies conducted in France on three species in which the species Anguilla anguilla (burrower and feeding in sediments) was found to be the most contaminated by trace elements (Noppe, 1996). The same is true for this species, which has higher Cd levels $\left(0.450 \mu \mathrm{g} \cdot \mathrm{g}^{-1}\right)$ in the lower Loukkos estuary in Morocco (El Morhit, 2009). The Cavally River fish serve as an important source of protein for the populations of the study area and even the city of Zouan-Hounien. Fish can, however, accumulate significant amounts of heavy metals from water and food, and can be used to monitor the level of pollutants in the river's waters. The fact that fish are also an important component of the diet raises concerns 
about risks to human health and biodiversity. So surface water is a danger to biodiversity.

\section{Conclusion}

This study examined the physico-chemical properties of surface waters to understand the state of water quality as well as the sources of pollutants. Surface waters are acidic with $\mathrm{pH}$ values between 4.78 and 6.94 and an average of 5.70. The values of the conductivities show that these waters are weakly mineralized, especially during the rainy season. Indeed, the low values of the conductivity are explained by the fact that the combination of physico-chemical conditions would lead to the precipitation and complexity of metals and inorganic salts. Analyses of the values of the redox potential and the dissolved oxygen show that all the waters are in oxidizing conditions and therefore well oxygenated in all seasons. This is explained by the fact that the watercourse of this basin is in permanent flow. It has clear waters, with regularly very low or no salinity levels. High turbidity values (between 103 and 170 NTU) in some surface water stations during dry seasons may indicate anthropogenic activity. This study showed a good correlation between the high values of surface water turbidity and the proximity of gold washing sites. Regarding nutrients, the deterioration of water quality in the study area is mainly related to alterations by nitrates, phosphates and sulphates. These elements come mainly from the degradation of the organic matter present in the medium or in the soils leached by the rains (decomposition of the plants and the animals), but also of compounds resulting from the human activity. Surface waters contain many dissolved elements, the most important of which are sodium $(\mathrm{Na})$, potassium $(\mathrm{K})$, iron $(\mathrm{Fe})$, calcium $(\mathrm{Ca})$. All these surface waters comply with WHO standards for the major elements studied. These results show that the concentrations of $\mathrm{As}, \mathrm{Cd}, \mathrm{Cu}, \mathrm{Ni}$ and $\mathrm{Pb}$ in these waters are relatively high in the great majority of the studied stations. Apart from $\mathrm{Cr}, \mathrm{Cu}$, $\mathrm{Hg}$ and $\mathrm{Zn}$, the other metals have levels that far exceed the potency standards set by WHO for the majority of stations, thus causing the deterioration of the quality of these waters. For the bioindicating species, the results obtained after analysis of samples showed that the fish (carp and machoiron) have concentrations in $\mathrm{Fe}, \mathrm{Cu}, \mathrm{Hg}$ and $\mathrm{Pb}$ higher than the existing standards (international, $\mathrm{FAO} /$ WHO) exposing the consumers to high risks for their health. Therefore, the use of these surface waters for agricultural irrigation and the consumption of fish from these waters could constitute the risk of bioaccumulation and toxicity and have negative impacts on the health of the population and on biodiversity. The presence of pollutants in these receiving environments is of natural origin but would be strongly accentuated by human activities (mining, agricultural and/or urban activities). Given the complexity of the study area, in order to predict the level of pollution in the coming years we recommend a regular and permanent monitoring. 


\section{Conflicts of Interest}

The authors do not declare any conflict of interest with respect to the publication of this article.

\section{References}

Afnor (1997). Water Quality (Volume 1): Terminology, Sampling and Evaluation Methods (3rd ed., 34 p). Paris: Afnor.

Aguiza, A. E., Ombolo A., Ngassoum, M. B., \& Mbawala, A. (2014). Monitoring of the Physicochemical and Bacteriological Quality of the Watercourses of Ngaoundéré, $\mathrm{Ca}$ meroon. Afrique Science, 10, 135-145.

Ahoussi, K. E., Koffi, Y. B., Kouassi, A. M., Soro, G., \& Biemi, J. (2013). Hydrochemical and Microbiological Study of Spring Water in the Mountainous West of Côte d'Ivoire: Case of Mangouin-Yrongouin Village (Biankouman Sub-Prefecture). Journal of Applied Biosciences, 63, 4703-4719. https://doi.org/10.4314/jab.v63i1.87245

Alloway, B. J. (1995). Soil Processes and Behavior of Heavy Metals. In B. J. Alloway (Ed.), Heavy Metals in Soils (368 p.). New York: Blackie Academic and Professional Publication. https://doi.org/10.1007/978-94-011-1344-1

Astorg, P., Couthouis, A., Bertrais, S., Arnault, N., Meneton, P., Guesnet, P., Alessandri, J. M., Galan, P., \& Hercberg, S. (2008). Association of Fish and Long-Chain n-3 Polyunsaturated Fatty Acid Intakes with the Occurrence of Depressive Episodes in Middle-Aged French Men and Women. Prostaglandins, Leukotrienes \& Essential Fatty Acids, 78, 171-182. https://doi.org/10.1016/j.plefa.2008.01.003

Atsé, A. R. M. (2007). Environmental Study of the Gold Bonikro Project in Côte d'Ivoire. Data Sheet Moged, Quebec: Institute of Energy and the Environment of the Francophonie.

Aubertin, M., Busnère, B., \& Bernier, L. (2002). Environment and Management of Mining Discharges. Montreal: Manual on CD-ROM, International Polytechnic Presses.

Brigde, G. (2004). Contest Terrain: Mining and the Environment and Resources. Annual Review of Environment and Resources, 29, 205-209.

https://doi.org/10.1146/annurev.energy.28.011503.163434

Burnol, A., Blanc, P., \& Guyonnet, D. (2004). Recommendations through Modeling of Metallic Transport in Groundwater. Final Report, BRG01/RP-52910, France.

Chouti, W., Mama, D., Changotade, O., Alapini, F., \& Boukari, M. (2010). Study of Metallic Trace Elements Contained in the Sediments of the Porto-Novo Lagoon (South Benin). Journal of Applied Biosciences, 34, 2186-2197.

Coulibaly, A. S., Mondé, S., Wognin, V. A., \& Aka, K. (2009). Analysis of Traces Metallic Elements (ETM) in the Estuarine Bays of Abidjan in Côte d'Ivoire. Afrique Science, 5, 77-96.

Daviglus, M. L., Stamler, J., Orencia, A. J., Dyer, A. R., Liu, K., Greenland, P., Walsh, M. K., Morris, D., \& Shekelle, R. B. (1997). Fish Consumption and the 30-Year Risk of Fatal Myocardial Infarction. The New England Journal of Medicine, 336, 1046-1053. https://doi.org/10.1056/NEJM199704103361502

De Villers, J., Squilbin, M., \& Yourassowsky, D. (2009). Physicochemical and Chemical Quality of Surface Water: General Framework. Environmental Data Observatory (pp. 2-16). Brussels: Brussels Institute for Environmental Management.

Diomandé, D., Doumbia, L., \& Gourène, G. (2009). Food Strategies of Two Fish-Cats Species in the Fluvio-Lacustre Hydrosystem of Bia: Synodontis Bastiani Daget, 1948 et S. Schall (Bloch \& Schneider, 1801). European Journal of Scientific Research, 27, 66-76. 
El Morhit, M. (2009). Hydrochemistry, Traces Metallic and Ecotoxicological Implications on the Different Components of an Estuarine Ecosystem (Bas Loukkos) (232 p). PhD Thesis, Maroc: Mohamed V-Agdal University.

Environment Canada (1980). Water Quality References, Guide to Water Quality Parameters.

Ettien, D. Z. (2005). Environmental and Population Impact Assessment Study of Mining in West Africa: Case of the Ity Gold Mine in the Semi-Mountainous Region of Western Côte d'Ivoire. Contribution of the Geographical Information System (S.I.G) and Remote Sensing (178 p.). PhD Thesis, Abidjan: University of Cocody.

Ettien, D. Z. (2010). Industrial Exploitation of Gold Deposits and Spatial Dynamics of the Ity Terroir in Western Côte d'Ivoire (15 p.). A Remote Sensing Study N 08.

Forstner, U., \& Wittmann, G. T. W. (1983). Metal Pollution in Aquatic Environment (2nd ed., p. 486). Berlin: Springer-Verlag.

Haddad, H., \& Ghoualem, H. (2014). Physico-Chemical Characterization of the Waters of the Coastal Basin of Algiers. Larhyss Journal, 18, 155-167.

Hade, A. (2002). Our Lakes-Know Them to Better Protect Them (Fides Editions, 360 p.).

He, K., Song, Y., Daviglus, M. L., Liu K., Van Horn, L., Dyer, A. R., Goldbourt, U., \& Greenland, P. (2004). Fish Consumption and Incidence of Stroke: A Meta-Analysis of Cohort Studies. Stroke, 35, 1538-1542.

https://doi.org/10.1161/01.STR.0000130856.31468.47

Hirose, K., Takezaki, T., Hamajima, N., Miura, S., \& Tajima, K. (2003). Dietary Factors Protective against Breast Cancer in Japanese Premenopausal and Postmenopausal Women. International Journal of Cancer, 107, 276-282. https://doi.org/10.1002/ijc.11373

Huang, T. L., Zandi, P. P., Tucker, K. L., Fitzpatrick, A. L., Kuller, L. H., Fried, L. P., Burke, G. L., \& Carlson, M. C. (2005). Benefits of Fatty Fish on Dementia Risk Are Stronger for Those without APOE Epsilon 4. Neurology, 65, 1409-1414. https://doi.org/10.1212/01.wnl.0000183148.34197.2e

Hughes, M. C., Williams, G. M., Fourtanier, A., \& Green, A. C. (2009). Food Intake, Dietary Patterns, and Actinic Keratoses of the Skin: A Longitudinal Study. The American Journal of Clinical Nutrition, 89, 1246-1255. https://doi.org/10.3945/ajcn.2008.27053

Keumean, K. N., Bamba, S. B., Soro, G., Soro, N., Métongo, B. S., \& Biemi, J. (2013). Concentration of Heavy Metals Sediments of the Estuary of the Comoé River. Journal of Applied Biosciences, 61, 4530-4539. https://doi.org/10.4314/jab.v61i0.85599

Koné, T., Kouamélan, E. P., Ouattara, N. I., \& Kicho, A. V. (2007). Diet of Pomadasys Jubelini (Pisces, Haemulidae) in a West African Lagoon (Ebrié Lagoon, Côte d'Ivoire). Sciences \& Nature, 4, 65-73. https://doi.org/10.4314/scinat.v4i1.42131

Kris-Etherton, P. M., Harris, W. S., \& Appel, L. J. (2002). Fish Consumption, Fish Oil, Omega-3 Fatty Acids, and Cardiovascular Disease. Circulation, 106, 2747-2757. https://doi.org/10.1161/01.CIR.0000038493.65177.94

Lévêque, C., Paugy, D., \& Teugels, G. G. (1990). Freshwater and Brackish Fishes Fauna of West Africa (Volume 1, 386 p.). ORSTOM Editions, Tropical Fauna Collection 28.

Makhoukh, M., Sbaa, M., Berrahou, A., \& Vanclooster, M. (2011). Contribution to the Study of the Impact of an Abandoned Mining Site in Upper Moulouya on the Quality of Oued Moulouya, Morocco. Afrique Sciences, 7, 34-48.

Morris, M. C., Evans, D. A., Bienias, J. L., Tangney, C. C., Bennett, D. A., Wilson, R. S., Aggarwal, N., \& Schneider, J. (2003). Consumption of Fish and n-3 Fatty Acids and Risk of Incident Alzheimer Disease. Archives of Neurology, 60, 940-946. 
https://doi.org/10.1001/archneur.60.7.940

Mounia, C. (2013). Analysis and Speciation of Metals in a Wadi in the Mining Zone (146 p.). PhD Thesis, Constantine: Constantine I University, Faculty of Exact Sciences, Department of Chemistry.

Naho, J. (1988). Supergene Cycle of Gold in Ferralitic Medium. Example of the Ity Gold Deposit in Côte d'Ivoire (132 p.). PhD Thesis in Geoscience and Raw Material, INPL, Nancy.

Noppe, K. (1996). Metallic Contamination of the Sediments of the Streams of the Artois-Picardie Basin and Its Impact on the Contamination of Fish Flesh and Livers (42 p.). Paris: Mémoire de DEA, Pierre and Marie Curie University VI.

Ouedraogo, M. (2001). Contribution to the Study of the Impact of Climate Variability on Water Resources in West Africa. Analysis of the Consequences of Persistent Drought: Hydrological Standards and Regional Modeling (257 p.). Thesis, Montpellier: University of Montpellier II.

Ouedraogo, M. F., Mtlesje, J. P., Feybesse, J. L., Ledru, P., Dommanget, A., Marcoux, E., Post, A., Vinchon, C., Sylvain, J. P., Johan, V., Teygyfy, M., Calvez, J. Y., \& Lagny, P. (1989). The Gold Mineralization of West Africa, Its Lithostructural Evolution at the Lower Proterozoic, Chron. Rech. Mine. Fr., No. 497.

Papon, A. (1973). Geology and Mineralization of South-West Côte d'Ivoire: Summary of the Work of SASCA 1962-1968 (285 p.). Brief BRGM, No. 80.

Pétré, M. A. (2008). Study of the Speciation of Dissolved Metals in Seine, Relationship with $\mathrm{pH}$ and Dissolved Organic Matter (46 p.). Master 2, Paris: Pierre and Marie Curie University, Ecole des Mines de Paris and National School of Rural Engineering and Water and Forests.

Ripley, E. A., Redman, R. E., \& Gowder, A. A. (1996). Environmental Effects of Mining. Delray Beach, FL: Saint Lucie Press.

Rodier, J. (2009). Water Analysis: Natural Waters, Residual Waters, Sea Water (9th ed., pp. 100-110). Paris: Dunod.

Scott, C. H. (2002). Aboriginal Autonomy and Development in Northern Quebec and Labrador. Vancouver and Toronto: University of British Columbia Press.

Servat, E., Paturel, J. E., Kouame, B., Travaglio, M., Ouedraogo, M., Boyer, J. F., LubesNiel, H., Fritsch, J. M., Masson, J. M., \& Marieu, B. (1998). Identification, Characterization and Consequences of Hydrological Variability in West and Central Africa (pp. 323-337). IAHS Publication No. 252.

Sirven, J. B. (2006). Detection of Heavy Metals in Soils by Laser Induced Plasma Emission Spectroscopy(252 p.). PhD Thesis, Bordeaux: University Bordeaux 1.

Timonen, M., Horrobin, D., Jokelainen, J., Herva, A., \& Räsänen, P. (2004). Fish Consumption and Depression: The Northern Finland 1966 Birth Cohort Study. Journal of Affective Disorders, 82, 447-452. https://doi.org/10.1016/j.jad.2004.02.002

Touré, N., Yao, K. A., Alui, K. A., \& Guety, T. P. (2010). Evaluation in Major Elements and Metallic Traces of an Agricultural Producer Environment in the Niéki Valley in the South-East of Côte d'Ivoire. Journal of Applied Biosciences, 34, 2134-2144.

Vo Quang, T., \& de Guyon, M. (1966). General Study of the Man Area. Agricultural Summary Report (pp. 7-17). Paris: Office for the Development of Agricultural Production (B.D.P.A).

Weber, T. (2006). Experimental Study and Modeling of the Modes of Association of Iron with Matter Natural Organic (120 p). PhD, Paris: UPMC Pierre and Marie Curie University. 
Yao, K. M., Soro, M. B., Albert, T., \& Bokra, Y. (2009). Assessment of Sediments Contamination by Heavy Metals in a Tropical Lagoon Urban Area (Ebrié Lagoon, Côte d'Ivoire). European Journal of Scientific Research, 34, 280-289.

Zinsou, H. L., Hermas, A. A., Pierre, G., Delphine, A., \& Philippe, L. (2016). Physico-Chemical Characteristics and Water Pollution of the Oueme Delta in Benin. Journal of Applied Biosciences, 97, 9163-9173. https://doi.org/10.4314/jab.v97i1.3 